\title{
Two new bairdiid ostracod species from the early Barremian-Hauterivian of the northern and central North Sea to the Atlantic margin off Norway
}

\author{
Michael Ayress and Tom Gould \\ RPS Ichron, Gadbrook Business Centre, Northwich, Cheshire CW9 7TL, UK
}

Correspondence: Michael Ayress (mike.ayress@rpsgroup.com)

Published: 23 January 2018

\begin{abstract}
Two new species of bairdiid Ostracoda are described from the lower Barremian - Hauterivian interval of the Valhall and Åsgard formations in the northern and central North Sea and Atlantic margin off Norway. The new species are Pontocyprella valhalla (lsid:zoobank.org:act:CA6B273F-CFF6-4C38-B9F4-18188225A711, 18 January 2018) and Bairdia asgarda (lsid:zoobank.org:act:4A4DC817-A028-45FB-9287-ABF3794F2FCB, 18 January 2018). These species dominate the ostracod assemblage that occurs abundantly in early BarremianHauterivian deep marine sediments of the northern and central North Sea and Haltenbanken area off Norway. Pontocyprella valhalla is restricted to this interval and because of its large size and distinct shape is a useful stratigraphic marker species, its last appearance being within the early Barremian.
\end{abstract}

As a consequence of drilling for hydrocarbons in the northern North Sea and Atlantic Margin, a considerable number of palaeontological data now exists from the Early Cretaceous interval, represented in the UK sector by the Valhall Formation (Johnson and Lott, 1993) and in the Norwegian sector by the Åsgard Formation (Isaksen and Tonstad, 1989). Palaeontological observations and microfossil counts frequently include Ostracoda. Ostracod shells are unusually common in drill cuttings and core samples from the Valhall and Åsgard formations. This abundance is undoubtedly due to the nature of their preservation as robust calcite-filled carapaces relatively resistant to abrasion. The ostracod assemblage is very distinct in that it comprises largely nonornate species, a characteristic that has apparently deterred their study by micropalaeontologists, presumably since such smooth shells offer few features that can be used for species discrimination. In addition, lack of disarticulated shells has impeded examination of internal diagnostic details. Here we describe two species of bairdiids that dominate the early Barremian-Hauterivian ostracod assemblage, and we show that they can be easily recognised by virtue of their distinctive shape and large size. The abundance, recognisability, and short range of one of the species, Pontocyprella valhalla $\mathrm{n}$. sp., makes it a useful stratigraphic marker species.

\section{Material and methods}

Observations documented herein are based on a large number of proprietary data examined over the last 30 years during routine biostratigraphical analyses of wells drilled in the North Sea and Atlantic margin off Norway. Access was granted to material that is particularly well preserved in the Wintershall Norge AS well 35/12-5S, North Viking Graben, latitude $61^{\circ} 13^{\prime} 0.65^{\prime \prime} \mathrm{N}$, longitude $3^{\circ} 49^{\prime} 39.29^{\prime \prime} \mathrm{E}$. The type specimens selected for this report are from 35/12-5S, collected from a ditch cutting sample at $2794 \mathrm{~m}$ (depth below KB). All complete specimens collected from the entire interval of occurrence, 2779 to $2842 \mathrm{~m}$, were used for measuring specimen length : height plots. Statements herein regarding the stratigraphical and geographical distribution of the species are based on observations pertaining to proprietary data from some 200 well sections drilled in the North Sea and North Atlantic continental shelf.

Outline illustrations presented in Fig. 1 are drawn from digital camera images. 


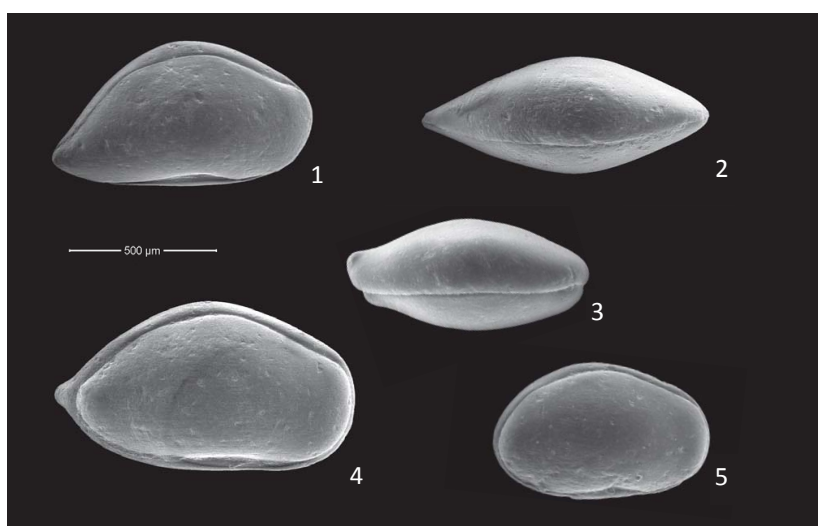

Plate 1. Scale bar is $100 \mu \mathrm{m}$. All specimens are from the ditch cutting sample at $2794 \mathrm{~m}$, well 35/12-5S. Nos. (1-2): Bairdia asgarda n. sp.: (1) paratype OS Cat no. 19866, carapace, right view, adult female; (2) paratype OS Cat no. 19864, carapace, dorsal view, adult female. Nos. (3-5): Pontocyprella valhalla $\mathrm{n}$. sp.: (3) paratype OS Cat no. 19869, carapace, dorsal view, adult male; (4) paratype OS Cat no. 19868, carapace, right view, adult male; (5) paratype OS Cat no. 19879, carapace, right view, A-1? female.

\section{Systematic palaeontology}

The following abbreviations are used: $\mathrm{L}$ is length, $\mathrm{H}$ is height, $\mathrm{A}$ is adult, and $\mathrm{C}$ is carapace. Type and figured specimens are housed at the Department of Earth Sciences, Museum of Natural History, London, and are curated with the prefix "NHMUK PM OS" abbreviated herein to "OS". Sample depths are measured depths (MD) from kelly bushing.

Class Ostracoda Latreille, 1806

Order Podocopida Sars, 1865

Suborder Bairdiocopina Sars, 1865

Superfamily Bairdioidea Sars, 1865

Family Bairdiidae Sars, 1865

Genus Bairdia McCoy, 1844

The Bairdiidae are well known for their conservative morphology and long upper Palaeozoic to Holocene stratigraphic range. Maddocks (1969) revised living bairdiids with emphasis placed on internal shell features and soft parts to identify genera. Workers on post-Palaeozoic bairdiids have had varying success in recognising these genera. We concur with Bate (1972) that there still remain smooth forms, which have a broadly convex dorsal outline and a tapered posterior with slightly upturned posterior end, such as in the present material, which cannot be satisfactorily placed in genera recognised by Maddocks. For the following species (Bairdia asgarda n. sp.) only carapace specimens have been found, which, although transparent, have not revealed internal details. Consequently, a clear intra-bairdiid assignment is not possible. We prefer, therefore, to consider this species Bair-

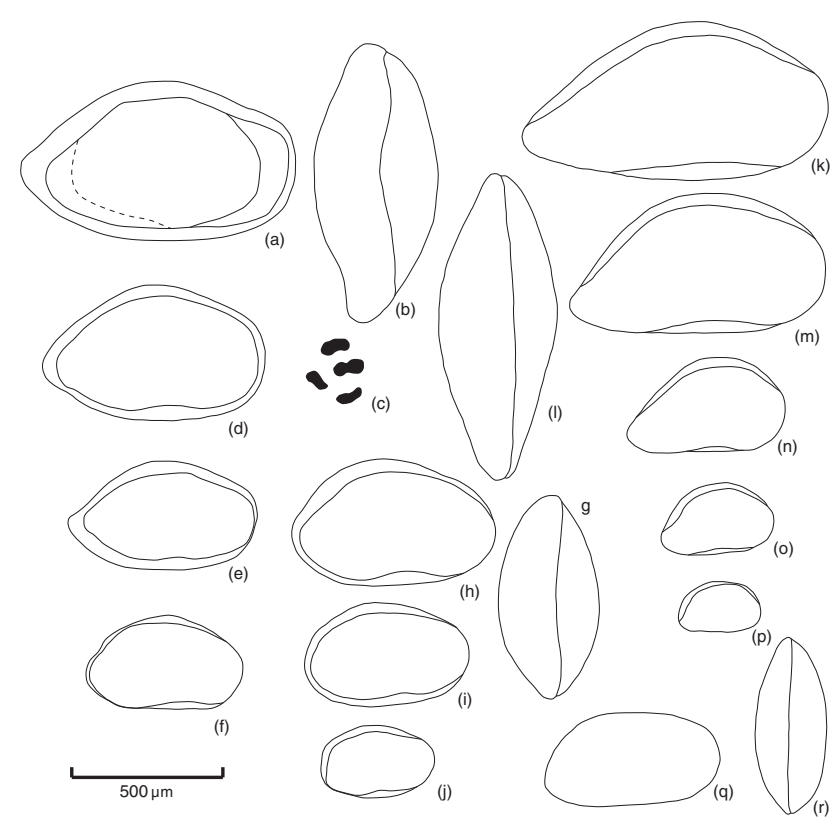

Figure 1. Scale bar is $100 \mu \mathrm{m}$. All specimens are from the ditch cutting sample at $2794 \mathrm{~m}$, well 35/12-5S. Letters (a-j): outline drawings of Pontocyprella valhalla $\mathrm{n}$. sp. showing sexual dimorphs and ontogenetic development of instars A-4 to adult. (a-c) Holotype OS Cat no. 19867, male carapace; (a) right view; (b) dorsal view; (c) adductor muscle scars right external view, magnification $\times 100$; (d) A-1 male carapace, OS Cat no. 19873, right view; (e) A-2 male carapace, OS Cat no. 19874, right view; (f) A-3 male carapace, OS Cat no. 19875, right view; (g-h) A-1 female carapace, OS Cat no. 19876; (g) dorsal view; (h) right view; (i) A-3 female carapace, OS Cat no. 19877, right view; (j) A-4 female carapace, OS Cat no. 19878, right view. Letters (k-p): outline drawings of Bairdia asgarda $\mathrm{n}$. sp. showing ontogenetic development of instars A-4 to adult. Letters (k-l): holotype OS Cat no. 19859, male carapace; (k) right view; (l) dorsal view; (m) female carapace OS Cat no. 19860, right view; (n) A-1 carapace OS Cat no. 19861, right view; (o) A-2 carapace OS Cat no. 19862, right view; (p) A-3 carapace OS Cat no. 19863, right view. Letters $(\mathbf{q}, \mathbf{r})$ : outline drawings of Pontocyprella sp. probable juvenile, OS Cat no. 19880; (q) carapace, right view; (r) dorsal view.

dia sensu lato until such a time when further details are available.

Bairdia asgarda n. sp. (Pl. 1, figs. 1-2; Figs. 1k-p, $2 \mathrm{a}-\mathrm{c})$

Derivation of name: From the Åsgard Formation where this species commonly occurs.

Diagnosis: A species of Bairdia within the Early Cretaceous of the North Sea oilfields, characterised by a pyriform to subtriangular carapace, arched dorsally, with acuminate anterior and posterior margins; the caudal extremity is ventrally situated. 

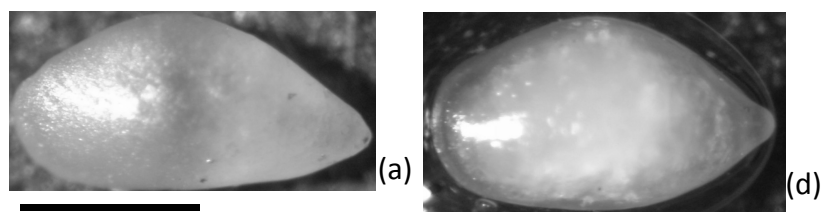

$0.5 \mathrm{~mm}$
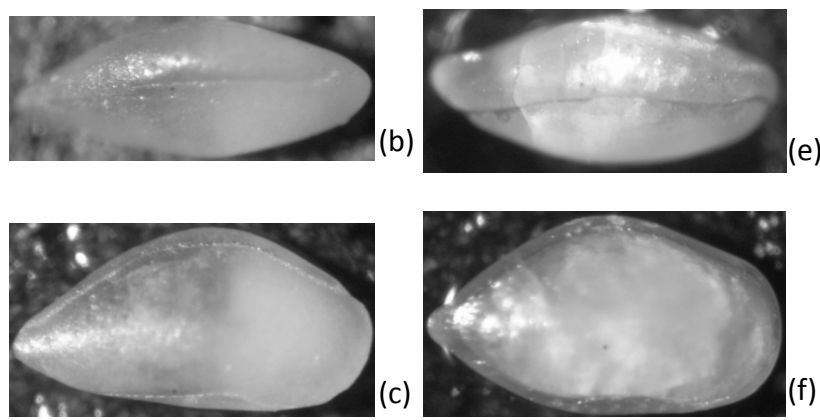

Figure 2. Scale bar is $100 \mu \mathrm{m}$. Light photography of holotypes. Both specimens are from ditch cutting sample $2794 \mathrm{~m}$, well 35/125S. (a-c) Holotype: male carapace, Bairdia asgarda n. sp., OS Cat no. 19859. (a) Left view, (b) dorsal view, (c) right view. (df) Holotype: male carapace, Pontocyprella valhalla n. sp., OS Cat no. 19867, (d) left view, (e) dorsal view, (f) right view.

Holotype: One complete male carapace, OS Cat no. 19859. The holotype is illustrated in Figs. 1k and 2a to c.

Paratypes: OS Cat nos. 19860-19866.

Material: There are 200 specimens from ditch cutting samples from 2779 to $2842 \mathrm{~m}$, well $35 / 12-5 \mathrm{~S}$.

Type locality and horizon: Ditch cutting sample at $2794 \mathrm{~m}$ in Well 35/12-5S, northern North Sea. Late Hauterivian.

Description: Carapace is large, moderately well calcified, pyriform to subtriangular in lateral view, lenticular in dorsal view. Left valve larger than the right, strongly overlapping dorsally and mid-ventrally. Maximum length below mid-height at ventral caudal apex. Maximum height and maximum width at mid-length. Dorsal margin in left valve arched to broadly convex, in right valve truncate through median third of length; anterior and posterior slopes slightly concave, the latter long and relatively steep. Ventral margin in left valve slightly convex, in right valve convex with concavity through median third of carapace length. Anterior margin weakly convex with distinct dorsal shoulder. Posterior margin with a distinct bairdiid ventral projection ventrally and slightly upturned. Surface smooth. Weakly sexually dimorphic: males more elongate and less inflated than females. Internal features not visible.
Dimensions:

\begin{tabular}{lllll}
\hline & & & $\mathrm{L}$ & $\mathrm{H}$ \\
\hline Holotype & OS Cat no. 19859 & Male AC & $1.00 \mathrm{~mm}$ & $0.49 \mathrm{~mm}$ \\
Paratype & OS Cat no. 19860 & Female AC & $0.83 \mathrm{~mm}$ & $0.47 \mathrm{~mm}$ \\
Paratype & OS Cat no. 19861 & Juvenile A-1C & $0.50 \mathrm{~mm}$ & $0.31 \mathrm{~mm}$ \\
Paratype & OS Cat no. 19862 & Juvenile A-2C & $0.37 \mathrm{~mm}$ & $0.23 \mathrm{~mm}$ \\
Paratype & OS Cat no. 19863 & Juvenile A-3C & $0.27 \mathrm{~mm}$ & $0.16 \mathrm{~mm}$ \\
Paratype & OS Cat no. 19864 & Female AC & $0.88 \mathrm{~mm}$ & $0.50 \mathrm{~mm}$ \\
Paratype & OS Cat no. 19865 & Female AC & $0.90 \mathrm{~mm}$ & $0.51 \mathrm{~mm}$ \\
Paratype & OS Cat no. 19866 & Female AC & $0.89 \mathrm{~mm}$ & $0.50 \mathrm{~mm}$ \\
\hline
\end{tabular}

Occurrence: Late Barremian - latest Ryazanian.

Distribution: Central and northern North Sea (UK and Norwegian Sectors), Haltenbanken region off Norway, and Danish North Sea.

Remarks: This species co-dominates with Pontocyprella valhalla $\mathrm{n}$. sp. in the ostracod assemblages that form a distinct faunal assemblage in the early Barremian-Hauterivian of the northern and central North Sea basins and Atlantic margin off Norway. However, unlike $P$. valhalla we have recorded B. asgarda at higher levels, in the late Barremian, although its precise last appearance datum is uncertain. Also, it ranges into older Valanginian and the latest Ryazanian strata where it is less abundant.

Early instars (Fig. 1o, p) can be confused with those of $P$. valhalla $\mathrm{n}$. sp. and other Pontocyprella spp. that are also frequently seen in the ostracod assemblage. However, the distinctly bairdiid shape - lenticular outline in dorsal aspect and overlap restricted to dorsal and mid-ventral regions - readily serve to distinguish juveniles as well as adults of $B$. asgarda.

Bairdia asgarda n. sp. is similar to Paracypris parallela Neale, 1962 from the Valanginian of the Speeton Clay, Yorkshire. Left and right valves are of a similar outline in P. parallela with little or no overlap, whereas the left valve of $B$. asgarda has a typical bairdiid outline with a strong dorsal overlap of the more triangular left valve.

Sexual dimorphs and instar stages were not readily separable from simple length: height ratios (Fig. 3). There appears to be a wide range of size variation in adults and juvenile stages. We found no relationship between size and stratigraphic occurrence within the Barremian to Hauterivian age range.

\section{Subfamily Bythocypridinae Maddocks, 1969}

Genus Pontocyprella Ljubimova, 1955

Type species: Bairdia harrisiana Jones, 1849. Some workers place Pontocyprella within Pontocypridinae. We consider Pontocyprella to belong to the subfamily Bythocypridinae Maddocks, 1969 on the basis of its carapace outline and its four adductor muscle scars (Fig. 1c) in a pattern similar to that of Bythocypris.

Pontocyprella valhalla $\mathrm{n}$. sp. (Pl. 1, figs. 3-5;

Figs. 1a-j, 2d-f) 
2000 Bairdia sp. 2 Ainsworth et al., p. 362

Derivation of name: From Valhall Formation, within which the type level occurs.

Diagnosis: A species of Pontocyprella characterised by an ovate and heavily calcified carapace, with a pronounced posterior projection at mid-height and anterior marginal thickening.

Holotype: One complete male carapace, OS Cat no. 19867. The holotype is illustrated in Figs. 1a and $2 \mathrm{~d}$ to $\mathrm{f}$.

Paratypes: OS Cat nos. 10-21.

Material: There are 40 specimens from ditch cutting samples at 2791 to $2800 \mathrm{~m}$, well $35 / 12-5 \mathrm{~S}$.

Type locality and horizon: Ditch cutting sample at 2794 m in Well 35/12-5S, northern North Sea. Late Hauterivian.

Description: Carapace large, heavily calcified, ovate in lateral and dorsal views. Left valve larger than the right, along all margins though less so anteriorly. Maximum height and maximum width at mid-length. Dorsal margin strongly convex. Ventral margin slightly convex, with small concavity just ahead of mid-length of carapace. Anterior margin weakly convex with slight marginal inflation that interrupts the ovate carapace outline in dorsal view. Posterior margin: males with a distinct projection of both valves, located at mid-height and, in dorsal view, slightly laterally directed; females with weak projected posterior or evenly convex. Carapace surface smooth. Sexually dimorphic: males more elongate than females. Inner lamella wide, avestibulate. Subcentral adductor muscle scars comprised of a loose circular aggregate of four subovate scars: three horizontally elongate ahead of the fourth scar, which is vertically elongate.

\section{Dimensions:}

\begin{tabular}{lllll}
\hline & & & $\mathrm{L}$ & $\mathrm{H}$ \\
\hline Holotype & OS Cat no. 19867 & Male AC & $0.95 \mathrm{~mm}$ & $0.52 \mathrm{~mm}$ \\
Paratype & OS Cat no. 19868 & Male AC & $1.02 \mathrm{~mm}$ & $0.58 \mathrm{~mm}$ \\
Paratype & OS Cat no. 19869 & Male AC & $0.97 \mathrm{~mm}$ & $0.55 \mathrm{~mm}$ \\
Paratype & OS Cat no. 19870 & Male AC & $0.80 \mathrm{~mm}$ & $0.41 \mathrm{~mm}$ \\
Paratype & OS Cat no. 19871 & Male AC & $0.81 \mathrm{~mm}$ & $0.46 \mathrm{~mm}$ \\
Paratype & OS Cat no. 19872 & Male AC & $0.82 \mathrm{~mm}$ & $0.44 \mathrm{~mm}$ \\
Paratype & OS Cat no. 19873 & Juvenile A-1C & $0.72 \mathrm{~mm}$ & $0.45 \mathrm{~mm}$ \\
Paratype & OS Cat no. 19874 & Juvenile A-2C & $0.66 \mathrm{~mm}$ & $0.38 \mathrm{~mm}$ \\
Paratype & OS Cat no. 19875 & Juvenile A-3C & $0.52 \mathrm{~mm}$ & $0.31 \mathrm{~mm}$ \\
Paratype & OS Cat no. 19876 & Female A-1C & $0.66 \mathrm{~mm}$ & $0.41 \mathrm{~mm}$ \\
Paratype & OS Cat no. 19877 & Female A-3C & $0.53 \mathrm{~mm}$ & $0.34 \mathrm{~mm}$ \\
Paratype & OS Cat no. 19878 & Female A-4C & $0.36 \mathrm{~mm}$ & $0.23 \mathrm{~mm}$ \\
Paratype & OS Cat no. 19879 & Female A-1C & $0.75 \mathrm{~mm}$ & $0.48 \mathrm{~mm}$ \\
\hline & & & &
\end{tabular}

Occurrence: The species occurs most abundantly in the early Barremian and late Hauterivian. Its last appearance is immediately below the Munk Marl Bed seen widely correlative across the North Sea region (eg. King et al., 1989). The first appearance datum is less well constrained as it is based on ditch cutting records, which are prone to artificially lower fossil species ranges due to caving contamination. We consider reliable records that first appear within the early Hauterivian.

Distribution: In the "deep-water biofacies" (King et al., 1989), Atlantic margin off Norway, northern and central North Sea (UK and Norwegian Sectors), a distribution extending from the Haltenbanken region to the Danish North Sea (Tuxen Formation, Valdemar Field).

Remarks: The posterior extension and anterior marginal thickening make this a very distinct species and serve to readily separate it from Bairdia asgarda $\mathrm{n}$. sp. and the type species of Pontocyprella, P. harrisiana (Jones, 1849). The four muscle scars were observed in two specimens including the holotype (Fig. 1c). The development of the posterior projection is variable. Forms with only a very weak posterior projection to almost completely rounded posterior are considered female dimorphs, and this condition is traceable through instars at least to A-4 (Fig. 1k to p). Instar stages were not readily separable using simple length:height measurements from the entire specimen collection (Fig. 4). Similar to Bairdia asgarda, there appears to be a wide range of juvenile stage and adult size variation. We found no relationship between size and stratigraphic level within the early Barremian to Hauterivian range. There is a close external morphological similarity of $P$. valhalla to species of Cophinia from the Late Cretaceous of the Portiguar Basin, northeastern Brazil (e.g. Piovesan, 2014). The similarity is superficial, however, as internal details differ: Cophina has a vertical row of adductor muscle scars, whereas $P$. valhalla has a round aggregate.

In the Britannia Field, central North Sea, Ainsworth et al. (2000) use the last appearance datum of this species (internal name Bairdia sp.2) to define the top of their zone BM11, within the lower Barremian of the lower part of the Valhall Formation.

\section{Discussion}

In addition to the two species described here, the early Barremian-Hauterivian ostracod assemblage also contains forms very similar to Pontocyprella harrisiana (Jones, 1849) and Pontocyprella rara Kaye, 1965, a more posteriorly pointed form. At present insufficient specimens in the material studied here preclude full comparisons, but the largest specimen we found is an instar whose outline has a steep posterior slope (Fig. 1q, r) similar to that of P. harrisiana. 


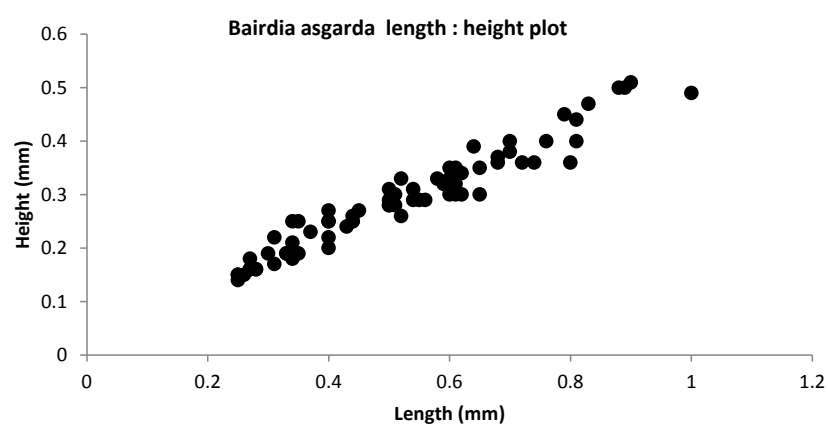

Figure 3. Length : height plot of specimens of Bairdia asgarda n. sp. Adults were recognised based on size alone (those longer than $0.8 \mathrm{~mm}$ ) as no internal details were observable. Juveniles collected in the census include immature stages back to A-4. The size distinction between them is blurred probably due to the multiple samples used.

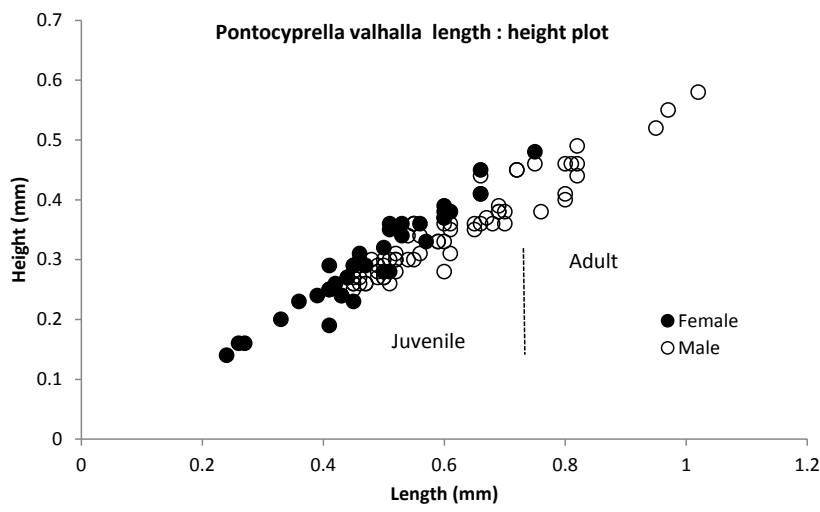

Figure 4. Length : height plot of specimens of Pontocyprella valhalla $\mathrm{n}$. sp. Adults were recognised by their fully developed inner lamella. Juveniles collected in the census include immature stages back to A-3. The size distinction between them is blurred probably due to the multiple samples used.

Onshore, P. harrisiana and P. rara have ranges of Aptian and Albian, respectively (Slipper, 2009). Offshore, in borehole $81 / 40$ in the western part of the central North Sea, Lott et al. (1985) show an occurrence of P. rara that extends down into the lowest levels of their study in the Barremian. We conclude that offshore ranges are probably older than onshore though further morphological comparisons are needed to confirm this.

Non-bairdiid species do occur in the central and northern North Sea early Barremian-Hauterivian ostracod assemblage but are not common. Worth noting is the ostracod index species Protocythere triplicata (Roemer, 1841) albeit it is very rare and is an occurrence consistent with the late Barremian-Hauterivian range seen onshore for this species (Neale, 1978; Slipper, 2009). Ayress and Dorn (2012) documented from the early Barremian-Hauterivian ostracod assemblage, which includes the bairdiid species described here, in wells 34/10-53A and 35/9-F-1H from the North Viking Graben, the earliest record of Aratrocypris Whatley et al. 1985 , a present-day widespread deep-sea genus.

Both the foraminifera and ostracod fauna of the lower Barremian-Hauterivian represent a very distinctive biofacies. Foraminifera commonly include Lenticulina spp. and agglutinated foraminifera including Falsogaudryinella praemoesiana Kaminski et al., 1995, which is indicative of an early Barremian-Hauterivian age (Kaminski et al., 1995). The biofacies has been interpreted as inhabiting "outer sublittoral-upper bathyal" palaeodepths (King et al., 1989) and a well oxygenated neritic environment (Gradstein et al., 1999).

Gradstein et al. (1999) present a zonation scheme using well material from several wells offshore Norway. Data from only one of the wells, 35/3-4, extends into the Barremian Hauterivian interval relevant here and is close to the 35/12$5 \mathrm{~S}$ well of the present study. The foraminiferal assemblage listed by them (Gradstein et al., 1999, Appendix A) from their "Hauterivian - Barremian time slice" is abundant and diverse with equal numbers of agglutinated and calcareous benthonic foraminifera. There are 22 benthonic species categorised as "common" constituents. Planktonic foraminifera are recorded as common and broadly grouped as Blefuscuiana. These are small and in the study area are usually found only in the late Barremian. The ostracods are mentioned as a broad grouping "Ostracoda (mostly smooth)" and are also given common status. In our present material, well $35 / 12-5 \mathrm{~S}$, Ostracoda comprise around $15 \%$ of the total Barremian - Hauterivian microfossils in any one sample. While the ostracods are subordinate to foraminifera, they are a distinct constituent of the biofacies being consistently common throughout the interval. No other Cretaceous interval of the North Sea oil fields area comprises such a high incidence of ostracods. Clearly Gradstein et al. (1999) recognises this and has indicated "ostracod last common occurrence (LCO)" on the Lower Cretaceous zonation (Gradstein et al., 1999, fig. 6).

The principal foraminiferal markers given by Gradstein et al. (1999) are Gavelinella barremiana (last occurrence (LO) at late Barremian boundary), Falsogaudryinella xenogena (LO mid-Barremian), Falsogaudryinella praemoesiana (LCO at late Hauterivian boundary), and Protomarssonella kummi (LO early Hauterivian). In the northern North Sea we observe that the "smooth" ostracods initially appear within the late Barremian (typically Bairdia as garda n. sp. and Pontocyprella species) coincident with $F$. xenogena. Pontocyprella valhalla $\mathrm{n}$. $\mathrm{sp}$. has its $\mathrm{LO}$ within the early Barremian, often coincident with the LO of $F$. praemoesiana, and its acme is also associated with the acme of F. praemoesiana at the Barremian-Hauterivian boundary. While the ostracod events serve as secondary markers, they do also provide confidence in recognising the assemblage biofacies as a whole. 
We have observed the distinctive early BarremianHauterivian ostracod assemblage, of which $P$. valhalla and B. asgarda are common components, to be distributed widely throughout the central and northern North Sea region and Atlantic margin off Norway. Lithostratigraphically, the fauna is typical of the lower part (lower Barremian-Hauterivian) of the Valhall Formation (UK sector) and coeval Norwegian sector strata including the Åsgard Formation and further north to the Haltenbanken, Lange, and Lyr formations. It has been observed in wells as far north as the Halten Terrace area off Norway. Towards the south it appears to have been confined somewhat by the mid-central North Sea high, being absent from wells in the Sole Pit Graben. However, it does occur abundantly in the Tail End Graben (Valdemar Field), which is the most southerly point at which we have observed the ostracod assemblage. It has not been documented in the microfauna reported from Heligoland (Bartenstein and Oertli, 1975).

\section{Conclusions}

An abundant early Barremian-Hauterivian ostracod assemblage is widely distributed in deep marine sediments (Valhall and Åsgard formations) from Haltenbanken off Norway, in the northern and central North Sea, to the Danish Basin. Despite this wide distribution there are no documented studies of the assemblage in the published literature. The assemblage is largely dominated by smooth-shelled species that offer, relative to ornate species at least, few features for taxonomic identification. We have focussed on two species that dominate the assemblage and can be readily identified. These are the bairdiid Ostracoda Pontocyprella valhalla n. sp. and Bairdia asgarda n. sp. Pontocyprella valhalla last occurs in the early Barremian immediately below the Munk Marl, and because of its large size and distinct shape it is a useful stratigraphic marker species there.

Data availability. Fossil occurrence data from well 35/12-5S are proprietary and not yet available in the public domain. Wintershall Norge AS have allowed the authors to publish information regarding the ostracod material described herein and the distribution data relating to this are available from the authors upon request.

Competing interests. The authors declare that they have no conflict of interest.

Acknowledgements. We thank Martin Carlsson of Wintershall Norge AS for allowing access to well material reported here. Nikki Khanna and John Chadwick of RPS Ichron read an early version of the paper and made useful positive comments. Scanning electron microscopy was carried out at the University of Manchester. Robin Ayress kindly assisted with the graphical plots. The two anonymous referees are thanked for their thoughtful constructive comments.

\section{References}

Ainsworth, N. R., Riley, L. A., and Gallagher, L. T.: An Early Cretaceous lithostratigraphic and biostratigraphic framework for the Britannia Field reservoir (Late Barremian-Late Aptian), UK North Sea, Petrol. Geosci., 6, 345-367, 2000.

Ayress, M. A. and Dorn, A.: A new record of Aratrocypris Whatley et al., 1985, Ostracoda, from the Lower Cretaceous of the North Sea: a range extension for the genus, J. Micropalaeontol., 31, 187-188, 2012.

Bartenstein, H. and Oertli, H.: Index ostracodes in the Lower Cretaceous of Heligoland, Bulletin du Centre de Recherches Pau, SNPA, 9, 5-25, 1975.

Bate, R. H.: Upper Cretaceous Ostracoda from the Carnarvon Basin, Western Australia, Spec. Pap. Palaeontol., 10, 1-85, 1972.

Gradstein, F. M., Kaminski, M. A., and Agterberg, F. P.: Biostratigraphy and paleoceanography of the Cretaceous seaway between Norway and Greenland, Earth-Sci. Rev., 46, 27-98, 1999.

Isaksen, D. and Tonstad, K.: A revised Cretaceous and Tertiary lithostratigraphic nomenclature for the Norwegian North Sea, NPD-Bulletin No. 5, 1989.

Johnson, H. and Lott, G. K.: 2. Cretaceous of the Central and Northern North Sea, in: Lithostratigraphic nomenclature of the UK North Sea, edited by: Knox, R. W. O'B. and Cordey, W. G., British Geological Survey, Nottingham, 1993.

Jones, T. R.: A monograph of the Entomostraca of the Cretaceous Formation of England, Palaeontogr., Soc. (Monograph), London, 40 pp., pls. 1-7, 1849.

Kaminski, M. A., Neagu, T., and Platon, E.: A revision of the Lower Cretaceous foraminiferal genus Falsogaudryinella from northwest Europe and Romania, and its relationship to Uvigerinammina, in: Proceedings of the Fourth International Workshop on Agglutinated Foraminifera, edited by: Kaminski, M. A., Geroch, S., and Gasiński, M. A., Grzybowski Foundation Special Publication, 3, 145-157, 1995.

Kaye, P.: Further Ostracoda from the British Lower Cretaceous, Senckenbergiana Lethaea, 46, 73-81, 1965.

King, C., Bailey, H. W., Burton, C. A., and King, A. D.: 8. Cretaceous of the North Sea, in: Stratigraphical Atlas of Fossil Foraminifera (Second Edition), edited by: Jenkins, D. G. and Murray, J. W., British Micropalaeontological Series, Ellis Horwood Ltd, Chichester, 1989.

Latreille, P. A.: Histoire Naturelle. Generale et Particuliare des Crustaces et des Insectes, 4, 232-254, 1806.

Lott, I. P., Ball, K. C., and Wilkinson, I. P.: Mid-Cretaceous stratigraphy of a cored borehole in the western part of the Central North Sea, P. Yorks. Geol. Soc., 45, 235-248, 1985.

Ljubimova, P. S.: Ostracody Melovykh Otlozheniy Vostochonoy Chasti Mongolskoy Narodonoy Republiki I ikh Znachenie dlya Stratigrafii [Ostracoda from Cretaceous deposits of the eastern part of the Peoples' Republic of Mongolia and their significance for stratigraphy], Trudy Vsesoyuznogo Nneftyanogo NauchnoIssledovatelskogo - Razvedochnogo Institua (VNIGRI), Novaya Seriya, 93, 1-174, 1955 (in Russian).

Maddocks, R. F.: Revision of recent Bairdiidae (Ostracoda), U. S. National Museum Bulletin, Washington, 296, 1-126, 1969.

McCoy, F.: A synopsis of characters of the Carboniferous limestone fossils of Ireland, Dublin, 163-168, pl. 23, 1844. 
Neale, J. W.: Ostracoda from the type Speeton clay (Lower Cretaceous) of Yorkshire, Micropaleontology, 8, 425-484, 1962.

Neale, J. W.: The Cretaceous, in: A stratigraphical Index of British Ostracoda, edited by: Bate, R. H. and Robinson, E., Geol. J., Special Issue, 8, 325-384, 1978.

Piovesan, E. K.: Ostracodes from the Upper Cretaceous deposits of the Potiguar Basin, northeastern Brazil: taxonomy, paleoecology and paleobiogeography. Part 2: Santonian-Campanian, Carnets de Géologie [Notebooks on Geology], 14, 315-351, 2014.

Roemer, F. A.: Die Versteinerungen des norddeutschen Kreidegebirges, Hahn'schen Hofbuchhandlung, Hannover, 145 pp., pls. $1-16,1841$.
Sars, G. O.: Oversigt af Norges Marine Ostracoder, Forhandlinger I Videnskabs-Selskabet I Cristiania, 1865, 1-130, 1865.

Slipper, I.: Marine Lower Cretaceous, in: Ostracods in British Stratigraphy, Whittaker, J. E. and Hart, M. B., The Micropalaeontological Society, Special Publications, 309-343, 2009.

Whatley, R. C., Ayress, M., Downing, S., Harlow, C., and Kesler, $\mathrm{K}$. : Aratrocypris, an enigmatic new cyprid ostracod from the Tertiary of D.S.D.P. sites in the S. W. Pacific, J. Micropalaeontol., 4, 69-79, 1985. 